27. Roscher AA, Schmid AJ, Hadorn B, Wiesmann UN 1980 Enhanced adenosine $3^{\prime}: 5^{\prime}$-monophosphate response to beta-adrenergic stimulation in cystic fibrosis fibroblasts after removal of conditioned medium. Pediatr Res 14:261

28. Roth JA, Rivett AJ 1982 Does sulfate conjugation contribute to the metabolic inactivation of catecholamines in humans? Biochem Pharmacol 31:3017

29. Rubin LS, Barabero GJ, Chernick WS 1966 Pupillary dysfunction as a concomitant of cystic fibrosis. Pediatrics 38:865

30. Schöni MH, Kraemer R, Bähler P, Rossi E 1984 Early diagnosis of cystic fibrosis by means of sweat microosmometry. J Pediatr 104:691

31. Strum J, Junod AF 1972 Autoradiographic demonstration of ${ }^{3} \mathrm{H}-5$-hydroxytryptamine uptake by pulmonary endothelial cells. J Cell Biol 54:456

32. Sturgess J, Reid L 1972 An organ culture study of the effect of drugs on the secretory activity of human bronchial submucosal gland. Clin Sci 43:533

33. Webster HL, Barlow WK 1981 New approach to cystic fibrosis diagnosis by use of an improved sweat-induction/collection system and osmometry. Clin Chem 27:385

\title{
Utilization of Galactose in Cultured Brain Cells of Neonatal Mice
}

\author{
H. P. SCHWARZ, K. GENNARI, H. P. SIEGRIST, K. ZUPPINGER, T. SCHÄFER, U. WIESMANN, \\ AND N. HERSCHKOWITZ \\ Universitäts-Kinderklinik, Inselspital, Bern, Switzerland
}

\begin{abstract}
Metabolism of galactose was examined in dissociated brain cells from neonatal mice after 10-13 days in culture. Consumption of galactose at levels up to $26 \mathrm{mM}$ was much less than consumption of glucose at corresponding concentrations. Lactate was consumed from the media at all galactose levels, in contrast to experiments with glucose in which lactate was formed and released into the media. Generation of $\mathrm{CO}_{2}$ from $4 \mathrm{mM}$ glucose was 9-fold greater than from an equimolar level of galactose. Relatively low concentrations of glucose could reduce uptake of galactose, whereas galactose at levels up to $11.6 \mathrm{mM}$ failed to inhibit consumption of glucose or formation of lactate. In glucose-deficient states, galactose supplementation of the media led to a marked increase in sulfatide synthesis by oligodendrocytes in the culture with a maximum effect at $2.3 \mathrm{mM}$. Under these conditions, $\left[1-{ }^{14} \mathrm{C}\right]$ galactose was incorporated directly into the carbohydrate portion of sulfatide, although most of the label was found in phospholipids and in the nonlipid fraction of the cellular homogenate. These data suggest that galactose is poorly metabolized by brain cells, but does not exhibit toxic effects. (Pediatr Res 19: 52-57, 1985)
\end{abstract}

\section{Abbreviations}

DMEM, Dulbecco's modified Eagle's medium DIC, days in culture

Under normal conditions galactose is efficiently metabolized by the liver. Conversion to glucose occurs by Leloir's pathway which is particularly active in neonatal mammals and involves three main steps. First galactose is phosphorylated by galactokinase (EC 2.7.1.6) to galactose-1-phosphate. This latter compound

Received April 2, 1984; accepted July 24, 1984.

Correspondence Dr. H. P. Schwarz, Universitäts-Kinderklinik, Inselspital, CH3010 Bern, Switzerland.

This work was supported by the Schweizerischer Nationalfonds zur Förderung der wissenschaftlichen Forschung Grants 3.419-0.78 and 3.963-0.80. is converted with UDPglucose by galactose-1-phosphate uridylyl transferase (transferase, EC 2.7.7.12) to UDPgalactose and glucose-1-phosphate. Finally, UDPgalactose is interconverted to UDPglucose by the enzyme UDPglucose 4-epimerase (epimerase, EC 5.1.3.2). While the highest specific activity of these enzymes is found in liver, lower activities can be demonstrated in many tissues including the brain. Compared to liver, brain activity in the adult rat amounted to $27 \%$ for galactokinase (7), $15 \%$ for transferase (2), and $52 \%$ for epimerase (5). Shin-Buehring et al. (26) reported that activity for the first two enzymes in the brain of human fetuses stayed at a low and fairly constant level between the 7 th and 28 th wk of gestation. Despite the presence of these enzymes, the mammalian brain is not dependent on preformed galactose for the synthesis of galactolipids, gangliosides, mucopolysaccharides, and glycoproteins, because the necessary UDPgalactose can be formed from UDPglucose catalyzed by the epimerase.

Under pathologic clinical conditions, as in transferase deficiency or galactokinase-deficiency galactosemia (24), high galactose plasma level may reach the brain. Mental retardation is a hallmark of untreated transferase-deficiency galactosemia and also has been described in galactokinase-deficient individuals. However, the exact pathogenesis is still not known. Animal models, such as the galactose-toxic rat and the chicken, have permitted some insight into the mechanism of galactose brain toxicity, but, admittedly, these models differ markedly from the human disease states and some studies yielded contradictory findings (25). The toxic effects of galactose on the CNS include decreased brain development and decreased DNA content (11), Schwann cell changes and demyelination (21), reduced cerebral entry and content of glucose $(10,14,16)$, inhibition of glycolysis $(10,17)$, and energy metabolism (10).

The neonatal mouse brain cell culture established by Wiesmann et al. (31) is a model which allows the investigation of the effects of exogenous substrates at the cellular level without interference from the blood brain barrier. It has been used before to study utilization of glucose (33), ketones, and oleate (4). In the present work, experiments were performed when the cultures were at a developmental stage characterized by a high number of oligodendrocytes (3) and active synthesis of sulfatide, a major 
galactolipid of myelin (27). Galactose was studied in these brain cell cultures in order to test its suitability as a substitute for glucose, to elucidate its metabolic interaction with glucose, and to define its role in galactolipid formation. Parts of this work have been published in abstract form $(9,23)$.

\section{MATERIALS AND METHODS}

Brain cell cultures. Dissociated brain cells were prepared according to Wiesmann et al. (31) with some modifications (33). Newborn mice from term-pregnancy Swiss albino dams (Hoffmann-La Roche, Füllinsdorf, Switzerland) were decapitated within $12 \mathrm{~h}$ after birth. The brains were immediately removed and mechanically dissociated in DMEM (Seromed GmbH, Munich, BRD) at room temperature. Aliquots of $15 \times 10^{6}$ cells were placed into $100-\mathrm{mm}$ plastic tissue culture dishes (Corning Glass Works, Corning, NY) containing a final volume of $10 \mathrm{ml}$ of DMEM enriched with $10 \%$ fetal calf serum, D-glucose $500 \mathrm{mg}$ / liter, L-glutamine $0.5 \mathrm{~g} /$ liter, sodium bicarbonate $2 \mathrm{~g} /$ liter, and penicilline $\mathrm{G}$, sodium salt, 100,000 units/liter. The initial lactate concentration in the medium was $1.9 \pm \mathrm{SD} 0.03 \mathrm{mM}$ and originated from the fetal calf serum. In experiments designed for ${ }^{14} \mathrm{CO}_{2}$ measurements, cultures were initiated in culture flasks (Falcon, Oxnard, CA) with $7 \times 10^{6}$ cells and $5 \mathrm{ml}$ of DMEM.

The cells were cultured in an incubator at $37^{\circ} \mathrm{C}$ with an atmosphere of $5 \% \mathrm{CO}_{2}$ and $95 \%$ air in $80 \%$ relative humidity. After the cultures had been left undisturbed for the first 6 days, media were replaced every other day with fresh enriched DMEM. Cell confluence was observed at day 6 and was complete by the 10th DIC. Oligodendrocytes as small, glowing, round cells began to appear around the 6th DIC and increased in numbers until the 10th DIC. They were present on the upper layer of the bilayered cell culture (33).

Experimental procedures. On the 10th DIC, media were replaced by DMEM containing glucose $(1.3-26.1 \mathrm{mM})$, galactose (1.3-26.3 mM), or both hexoses combined in various concentrations. $\mathrm{D}(+)$-glucose monohydrate and $\mathrm{D}(+)$-galactose (biochemical grade, E. Merck, Darmstadt, BRD), contained less than $0.1 \%$ of contaminants. On the 13 th DIC, aliquots of the media were removed and kept frozen at $-20^{\circ} \mathrm{C}$ until analyzed.

For measurement of sulfatide synthesis carrier-free $\mathrm{H}_{2}{ }^{35} \mathrm{SO}_{4}$ (The Radiochemical Centre, Amersham, England) $20 \mu \mathrm{Ci} / \mathrm{ml}$ medium was added to the cultures. If ${ }^{14} \mathrm{CO}_{2}$ generation was to be measured, D-[U- $\left.{ }^{14} \mathrm{C}\right]$ glucose $(345 \mathrm{mCi} / \mathrm{mmol})$ or $\mathrm{D}-\left[\mathrm{U}-{ }^{14} \mathrm{C}\right]$ galactose $(284 \mathrm{mCi} / \mathrm{mmol}) \perp \mu \mathrm{Ci} / 5 \mathrm{ml}$ medium was used. To study galactose incorporation into cell structures $\mathrm{D}-\left[1-{ }^{14} \mathrm{C}\right]$ galactose $(8 \mathrm{mCi} / \mathrm{mmol}) 1.2-2.4 \mu \mathrm{Ci}$ was pipetted to each culture. Incubations were continued for another $4 \mathrm{~h}\left({ }^{14} \mathrm{CO}_{2}\right.$ measurements), $6 \mathrm{~h}$ (galactose incorporation), or $24 \mathrm{~h}$ (sulfatide synthesis). The medium was then removed, the cells were washed with cold saline, harvested with a rubber policeman, centrifuged, and frozen at $-20^{\circ} \mathrm{C}$, and when used were disrupted by sonication for $30 \mathrm{~s}$ at $30 \mathrm{~W}$. All radiolabelled hexoses were obtained from New England Nuclear, Boston, MA.

Analytical procedures. Aliquots of the cell homogenate were used for lipid extraction (8) with determination of ${ }^{35} \mathrm{SO}_{4}$ incorporation into sulfatide (12), and for measurement of cellular protein (15). The lipid extract was counted after addition of Aquassure (New England Nuclear) in a Packard Tri-Carb Liquid Scintillation Spectrometer (Packard Instruments, Downers Grove, IL). Total lipids were separated by thin-layer chromatography on precoated silica gel plates (E. Merck, Darmstadt, BRD) according to Suzuki (29) using chloroform/methanol/water $65: 28: 4.5$ as solvent. Pure glycolipid and phospholipid standards were purchased from Applied Science, Oud-Beijerland, Holland. After separation the single lipid spots were delineated with iodine, scraped off, and counted. Hydrolysis of the glycolipids, cerebroside, and sulfatide, was achieved by elution of the respective spots from the silica gel with chloroform/methanol $2: 1$ in $5 \%$ water, drying of the upper phase under nitrogen, and heating of the dried residue with $5 \% \mathrm{HCl}$ in methanol. After extraction with petroleum ether, the upper phase contained free sphingosine and fatty acids, the lower phase contained the carbohydrate portions. Radioactivity was measured in both phases.

Production of ${ }^{14} \mathrm{CO}_{2}$ was measured as described by Bossi et al. (4). Carbon dioxide was trapped during the 4-h incubation on a filter soaked with $200 \mu \mathrm{l} \mathrm{NaOH} 0.5 \mathrm{~N}$ which had been placed into the center well of the cap of the culture flasks. Residual $\mathrm{CO}_{2}$ was expelled from the media at the end of the incubation and also trapped on a filter after addition of $250 \mu \mathrm{l} \mathrm{\textrm {HClO } _ { 4 }} 1 \mathrm{~N}$ to the medium. The filters were placed into Dimilume-30 (Packard Instrument Company, Rockford, IL) and the radioactivity was counted.

Glucose in the media was estimated by the hexokinase-glucose6-phosphate dehydrogenase method (Gluco-quant, Boehringer Mannheim $\mathrm{GmbH}, \mathrm{BRD}$ ), galactose by galactose dehydrogenase (Test-Combination Galactose, Boehringer). Lactate was determined with lactate dehydrogenase. Substrate consumption by the cultures was calculated from the concentration changes in the media. All reagents used were of analytical grade.

Results are expressed as mean \pm SD. For statistical analysis Student's $t$ test was used.

\section{RESULTS}

On the 10th DIC the brain cells were exposed to medium galactose levels ranging from 1.3-26.3 mM. Galactose consumption within the following 3 days increased from $2.5 \pm 0.4 \mu \mathrm{mol} /$ mg cell protein $\times 72 \mathrm{~h}$ at the lowest concentration, to $8.2 \pm 1.4$ at $13.3 \mathrm{mM}$ and $6.7 \pm 0.6$ at $26.3 \mathrm{mM}$ (Fig. $1 A$ ). Medium galactose levels did not drop below $1 \mathrm{mM}$ after 3 days if $2 \mathrm{mM}$ or more had been present initially. If glucose instead of galactose was offered at comparable concentrations to otherwise similar cell cultures, glucose uptake was rapid (Fig. $1 B$ ). At the lower concentrations up to $7.8 \mathrm{mM}$ glucose had virtually disappeared

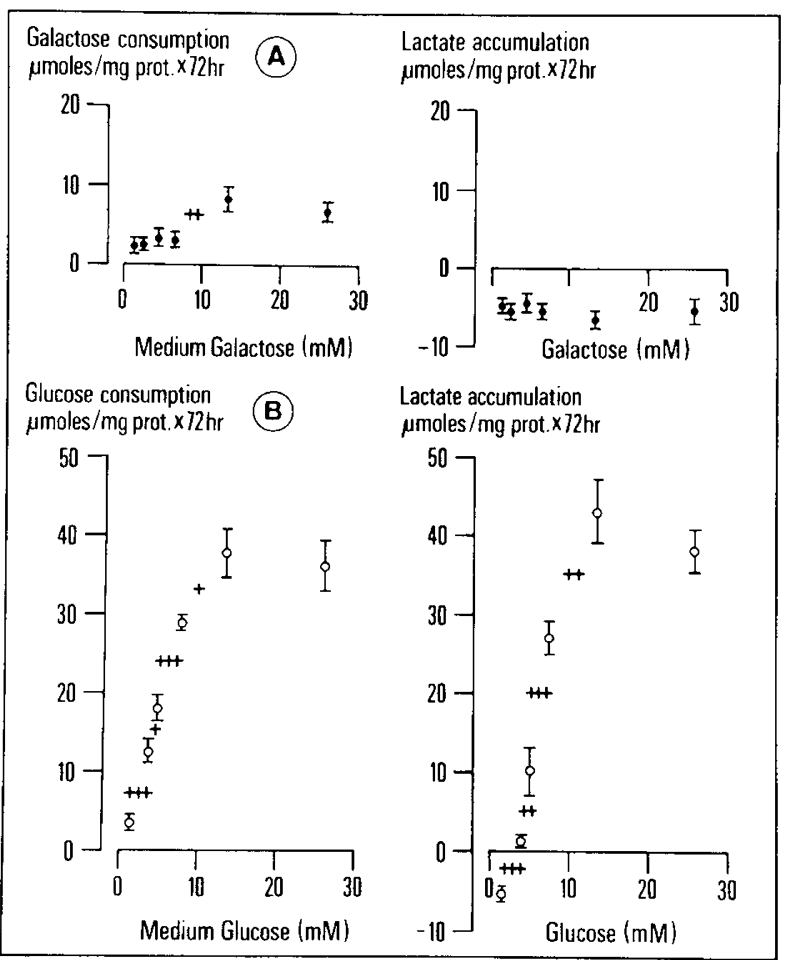

Fig. 1. Hexose consumption and lactate accumulation by mouse brain cells between day 10 and 13 in culture. Cells were cultured for 10 days and exposed to different galactose $(A)$ or glucose $(B)$ concentrations for another 3 days. Means $\pm \mathrm{SD}$ of three to four separate experiments in each group are given. Statistical difference:,$+ p<0.01 ;++, p<0.005$; ,$+++ p<0.001$. 
from the medium after 3 days leaving the cells glucose-deprived for various periods of time as was shown by Zuppinger et al. (33). At the two highest hexose levels tested, cellular consumption of glucose was about five times higher than consumption of galactose. The glucose consumption was paralleled by accumulation of lactate in the medium. By contrast, in experiments with galactose, lactate was actually taken up from the medium ("negative accumulation"). Thus, even at the highest galactose concentrations the cells consumed lactate as they did under the most severe glucose restriction (Fig. $1 A$ and $B$ ).

Metabolism of $\left[{ }^{14} \mathrm{C}\right]$ galactose to ${ }^{14} \mathrm{CO}_{2}$ was investigated in the presence of three different glucose levels (Fig. 2). Generation of ${ }^{14} \mathrm{CO}_{2}$ was dependent on the ambient glucose concentration and declined to $49 \%$ if the supply of glucose was increased from $0.5-$ $4 \mathrm{mM}$ at a constant $\left[{ }^{14} \mathrm{C}\right]$ galactose level of $4 \mathrm{mM}$. However, much more ${ }^{14} \mathrm{CO}_{2}$ was formed from $\left[{ }^{14} \mathrm{C}\right]$ glucose than from $\left[{ }^{14} \mathrm{C}\right]$ galactose. At equimolar levels, conversion from glucose to $\mathrm{CO}_{2}$ was nine times more rapid than conversion of galactose.

The effect of glucose on galactose consumption was assessed in experiments with both hexoses present. The more glucose added, the less galactose was consumed (Table 1). For reference, galactose consumption of $8.2 \pm 1.4 \mu \mathrm{mol} / \mathrm{mg}$ cell protein $\times 72$ $\mathrm{h}$ at $13.3 \mathrm{mM}$ initial galactose was expressed as $100 \pm 17 \%$. With high glucose concentrations galactose uptake was markedly depressed and could be totally abolished with $4.2 \mathrm{mM}$ galactose and $26.5 \mathrm{mM}$ glucose. On the other hand, galactose did not affect glucose uptake by the brain cells at high $(12.8 \mathrm{mM})$, intermediate (7.5 mM), or low (2.9 mM) initial levels (Table 2).

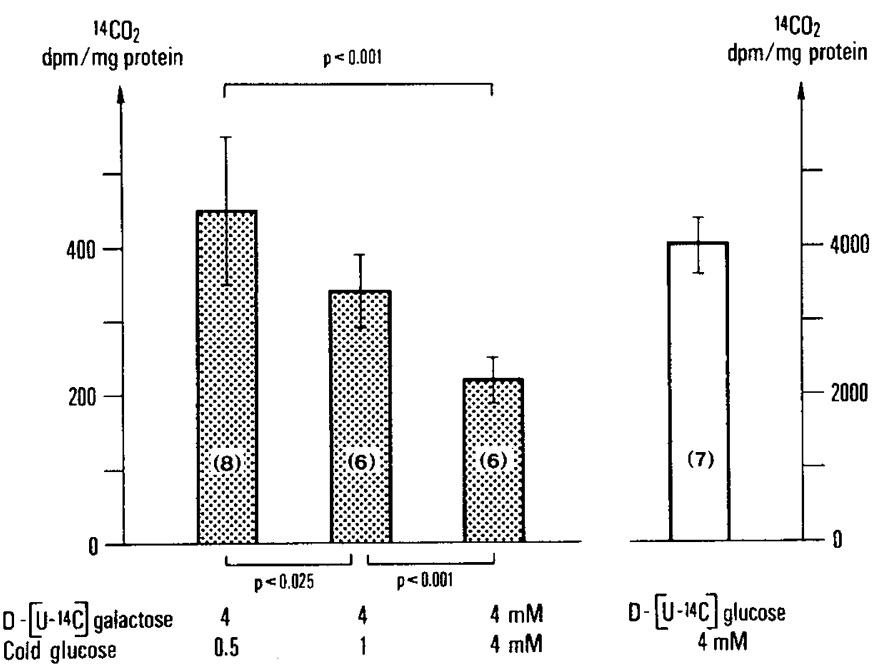

Fig. 2. Formation of ${ }^{14} \mathrm{CO}_{2}$ from $\mathrm{D}-\left[\mathrm{U}-{ }^{14} \mathrm{C}\right]$ galactose depending on medium glucose (dotted bars) or from $\mathrm{D}-\left[\mathrm{U}-{ }^{14} \mathrm{C}\right]$ glucose (open bar). Cells were grown for 13 days and exposed for $4 \mathrm{~h}$ to the indicated specific media (specific activity $0.05 \mathrm{mCi} / \mathrm{mmol}$ ). Means $\pm \mathrm{SD}$ of number of experiments in parentheses are given.

Table 1. Inhibition of galactose consumption by glucose in mouse brain cell cultures (days 10-13 in culture)*

\begin{tabular}{cccc}
\hline $\begin{array}{c}\text { Initial } \\
\text { galactose } \\
(\mathrm{mM})\end{array}$ & $\begin{array}{c}\text { Initial } \\
\text { glucose } \\
(\mathrm{mM})\end{array}$ & $\begin{array}{c}\text { Galactose } \\
\text { consumption }(\%)\end{array}$ & $\begin{array}{c}\text { No. of } \\
\text { experiments }\end{array}$ \\
\hline 13.3 & & $100.0 \pm 17.0$ & 3 \\
12.6 & 11.4 & $75.6 \pm 29.3$ & 6 \\
4.2 & & $40.2 \pm 4.9$ & 3 \\
3.8 & 6.4 & $14.6 \pm 12.2 \dagger$ & 3 \\
4.2 & 26.5 & $4.8 \pm 7.3$ & 3 \\
1.1 & 0.9 & $23.6 \pm 4.6$ & 7 \\
1.1 & 4.2 & $27.7 \pm 8.3$ & 8 \\
1.1 & 23.0 & $8.6 \pm 2.9 \dagger$ & 10 \\
\hline
\end{tabular}

* Mean \pm SD.

$\uparrow$ Significantly different from previous group $(p<0.05)$.
Formation of lactate from glucose was similar in the absence or in the presence of galactose. Furthermore, sulfatide synthesis was not affected by galactose as long as (high) glucose levels of 12 $\mathrm{mM}$ or more were provided. At these levels, the glucose concentration in the media was still at least $3 \mathrm{mM}$ or more after 3 days, a level which left the cultures amply supplied. Glucose deprivation (below $1 \mathrm{mM}$ ) lasted for 24 or $48 \mathrm{~h}$ at initial levels of 7.5 or $2.9 \mathrm{mM}$, respectively. Under these conditions, addition of 6.2 to $6.5 \mathrm{mM}$ galactose enhanced sulfatide synthesis by $77 \%$ at the higher and almost quadrupled it at the lower glucose level.

To characterize further the stimulative effect of galactose on sulfatide synthesis by cell cultures in glucose-deficiency states, cells were cultivated from day $10-13$ at constant initial glucose levels of $7.5 \mathrm{mM}$ with or without galactose (Table 3). This left the cells glucose deprived for at least $24 \mathrm{~h}$. Addition of galactose raised sulfatide synthesis significantly at levels as low as $1.1 \mathrm{mM}$. A maximum effect with an increase of sulfatide synthesis from a basal $5328 \pm 1858 \mathrm{dpm} / \mathrm{mg}$ cell protein without galactose to $12,213 \pm 645 \mathrm{dpm} / \mathrm{mg}$ protein was achieved after supplementation of the medium with $2.3 \mathrm{mM}$ galactose. No further enhancement was observed if high galactose levels up to $12.2 \mathrm{mM}$ were tested, although at this concentration consumption of galactose was clearly higher than at $2.3 \mathrm{mM}$ galactose when maximum rates of sulfatide synthesis were reached. In the absence of glucose, incorporation of ${ }^{35} \mathrm{SO}_{4}$ into sulfatide was similarly low over a wide range of galactose concentrations and amounted only to a fraction of that observed with glucose (Table 4). In the total absence of either glucose or galactose, ${ }^{35} \mathrm{SO}_{4}$ incorporation was $227 \pm 24 \mathrm{dpm} / \mathrm{mg}$ cell protein. There was no dependence of sulfatide synthesis on initial galactose levels as opposed to the strict linear correlation between sulfatide synthesis and glucose concentrations (33).

A next set of experiments was conceived to study galactose metabolism and to elucidate the mechanism whereby galactose increased sulfatide synthesis in glucose-deficient cell cultures. Incorporation of label from $\left[{ }^{14} \mathrm{C}\right]$ galactose into cellular structures was studied under three different conditions (Table 5). In group $\mathrm{A}$, the cultures were amply provided with glucose; group B experiments were carried out with glucose levels which fell below $1 \mathrm{mM}$ after $36 \mathrm{~h}$; in group C, glucose levels were below $1 \mathrm{mM}$ throughout the study. The data in the three groups were corrected to similar medium specific activity because extracellular galactose concentrations were dissimilar on the 13 th DIC when $\left[{ }^{14} \mathrm{C}\right]$ galactose was added. This was due to the different galactose uptake from the medium in relation to the different glucose levels (Table 1).

Compared to group A, more label was found in the cellular homogenate in groups B and C. Although most of the label was found in the nonlipid fraction in all groups, radioactivity in the lipids increased from $8 \%$ in group A to $15 \%$ in group B and $21 \%$ in group C. Subsequently, the total lipids were separated by thinlayer chromatography into single lipid fractions (Fig. 3). Most counts were contained in the major phospholipids (lysolecithin, sphingomyelin, phosphatidyl choline, serine, inositol, and ethanolamine): $78 \%$ in group A, $85 \%$ in group B, and $83 \%$ in group C. The glycolipids, sulfatide, and cerebroside fraction contained $81 \pm 21 \mathrm{dpm} / \mathrm{mg}$ cell protein (12\% of total) in group A, $172 \pm$ $4 \mathrm{dpm}$ in group B ( $8 \%$ of total), and $128 \pm 20 \mathrm{dpm}$ in group C (6\% of total). The glycolipids in group $\mathrm{B}$ were isolated and hydrolyzed into the carbohydrate, the sphingosine, and the fatty acid portions. In sulfatide, $81 \pm 4 \%$ of the radioactivity was found in the carbohydrate portion; in cerebroside $90 \pm 4 \%$ of the carbohydrate portion was labeled.

\section{DISCUSSION}

The results of this study demonstrate that cultured mouse brain cells between the 10th and 13th DIC do utilize galactose although at a much slower rate than they utilize glucose. At equimolar levels between 1.3-26.3 mM, galactose consumption 
Table 2. Comparative effect of glucose alone or in combination with galactose*

\begin{tabular}{|c|c|c|c|c|c|c|}
\hline $\begin{array}{c}\text { Initial } \\
\text { glucose } \\
(\mathrm{mM})\end{array}$ & $\begin{array}{c}\text { Initial } \\
\text { galactose } \\
(\mathrm{mM})\end{array}$ & $\begin{array}{c}\text { Consumption of } \\
\text { glucose } \\
(\mu \mathrm{mol} / \mathrm{mg} \text { cell } \\
\text { protein } \times 72 \mathrm{~h})\end{array}$ & $\begin{array}{c}\text { Consumption of } \\
\text { galactose } \\
(\mu \mathrm{mol} / \mathrm{mg} \text { cell } \\
\text { protein } \times 72 \mathrm{~h})\end{array}$ & $\begin{array}{c}\text { Formation of } \\
\text { lactate } \\
(\mu \mathrm{mol} / \mathrm{mg} \times \\
72 \mathrm{~h})\end{array}$ & $\begin{array}{c}\text { Formation of } \\
{ }^{35} \mathrm{SO}_{4} \text { sulfatide } \\
(\mathrm{dpm} / \mathrm{mg} \text { cell } \\
\text { protein) }\end{array}$ & $\begin{array}{c}\text { No. of } \\
\text { experiments }\end{array}$ \\
\hline 12.8 & & $51.9 \pm 6.2$ & & $62.8 \pm 7.8$ & $33,426 \pm 4,732$ & 6 \\
\hline 12.6 & 11.6 & $47.7 \pm 3.3$ & $6.2 \pm 2.4$ & $59.4 \pm 5.8$ & $30,583 \pm 3,246$ & 6 \\
\hline 7.5 & & $49.0 \pm 7.8$ & & $61.8 \pm 9.5$ & $5,328 \pm 1,858$ & 9 \\
\hline 7.5 & 6.2 & $42.3 \pm 3.7$ & $2.9 \pm 0.5$ & $56.2 \pm 2.9$ & $9,425 \pm 2,395 \dagger$ & 5 \\
\hline 2.9 & & $13.5 \pm 0.9$ & & $1.7 \pm 0.8$ & $582 \pm 89$ & 5 \\
\hline 3.0 & 6.5 & $13.2 \pm 1.0$ & $3.0 \pm 0.5$ & $1.4 \pm 1.1$ & $2,112 \pm 99 \ddagger$ & 5 \\
\hline
\end{tabular}

$*$ Mean \pm SD.

$\dagger$ Significantly different from previous group at $p<0.005$ or $\ddagger p<0.001$.

Table 3. Effect of glucose alone or in combination with different galactose concentrations on the incorporation of ${ }^{35} \mathrm{SO}_{4}$ into sulfatide*

\begin{tabular}{ccccc}
\hline $\begin{array}{c}\text { Initial } \\
\text { glucose } \\
(\mathrm{mM})\end{array}$ & $\begin{array}{c}\text { Initial } \\
\text { galactose } \\
(\mathrm{mM})\end{array}$ & $\begin{array}{c}\text { Galactose consumption } \\
(\mu \text { mol/mg cell protein } \\
\times 72 \mathrm{~h})\end{array}$ & $\begin{array}{c}{ }^{35} \mathrm{SO}_{4} \text {-sulfatide } \\
(\mathrm{dpm} / \mathrm{mg} \text { cell protein })\end{array}$ & $\begin{array}{c}\text { No. of } \\
\text { experiments }\end{array}$ \\
\hline 7.5 & & & $5,328 \pm 1,858$ & 9 \\
7.5 & 0.1 & $0.8 \pm 0.4$ & $3,946 \pm 1,244$ & 4 \\
7.5 & 0.6 & $1.5 \pm 0.3^{a}$ & $6,819 \pm 889$ & 4 \\
7.5 & 1.1 & $2.3 \pm 0.4^{b}$ & $8,472 \pm 2,791^{e}$ & 7 \\
7.5 & 2.3 & $3.5 \pm 0.4^{b}$ & $12,213 \pm 645^{f}$ & 3 \\
7.5 & 3.8 & $2.4 \pm 1.0$ & $10,834 \pm 1,430^{f}$ & 5 \\
7.5 & 6.2 & $2.9 \pm 0.5^{c}$ & $9,425 \pm 2,395^{g}$ & 6 \\
\end{tabular}

* Mean \pm SD.

Significantly different from previous group: ${ }^{a} p<0.05 ;{ }^{b} p<0.01 ;{ }^{c} p<0.02 ;{ }^{d} p<0.005$.

Significantly different from first group ("glucose only"): ${ }^{e} p<0.02 ;{ }^{f} p<0.001 ;{ }^{g} p<0.005$.

Table 4. Effect of galactose on the incorporation of ${ }^{35} \mathrm{SO}_{4}$ into sulfatide*

\begin{tabular}{ccc}
\hline $\begin{array}{c}\text { Initial } \\
\text { galactose } \\
(\mathrm{mM})\end{array}$ & $\begin{array}{c}{ }^{35} \mathrm{SO}_{4} \text {-sulfatide } \\
(\mathrm{dpm} / \mathrm{mg} \text { cell protein })\end{array}$ & $\begin{array}{c}\text { Relative value } \dagger \\
(\%)\end{array}$ \\
\hline 26.3 & $2188 \pm 231(4)$ & $2.9 \pm 0.3$ \\
13.3 & $1826 \pm 380(3)$ & $2.7 \pm 0.6$ \\
6.4 & $1146 \pm 84 \ddagger(3)$ & $2.4 \pm 0.2$ \\
4.2 & $1431 \pm 408(3)$ & $8.7 \pm 2.5$ \\
2.2 & $1553 \pm 639(3)$ & $21.5 \pm 8.8$ \\
\hline
\end{tabular}

* Mean \pm SD of three to four separate experiments per group.

$\dagger \mathrm{dpm}{ }^{35} \mathrm{SO}_{4}$-sulfatide in percent of dpm found in experiments with comparable glucose concentrations.

$\ddagger$ Significantly different from previous group $(p<0.05)$.

was 1.4-9.4 times less than glucose consumption (Fig. 1). Similarly, the rate of ${ }^{14} \mathrm{CO}_{2}$ generation from $\left[{ }^{14} \mathrm{C}\right]$ galactose was about one-ninth of the rate with $\left[{ }^{14} \mathrm{C}\right]$ glucose (Fig. 2). This could be due either to slow uptake of galactose at the cellular membrane, a low rate of intracellular metabolism, or a combination of both. Transport of a substrate into the brain need not parallel its metabolism. Metabolism is probably nonexistent for 3-O-methylD-glucose and only partial for 2-deoxy-D-glucose, yet these substrates freely penetrate the blood brain barrier (18).

Glucose uptake can be regulated at the cellular membrane or at the level of the phosphorylating enzymes, depending on the cell type (13). In our cell cultures extracellular factors did not seem to affect glucose utilization because the initial glucose consumption was shown to be independent of the medium glucose concentrations at levels above $1 \mathrm{mM}$ (33). Galactose uptake into the brain is effected by a carrier-mediated transport system which is shared by other hexoses. The $\mathrm{K}_{\mathrm{m}}$ of this system is $40 \mathrm{mM}$ for galactose and $9 \mathrm{mM}$ for glucose (19). Accordingly, the brain uptake index for galactose measured in the intact rat was less than one-half that for glucose (18). As a consequence, uptake of galactose is inhibited by relatively low concentrations of glucose, whereas large concentrations of galactose are necessary to inhibit glucose uptake. Our data are compatible with these findings. Galactose consumption in our system was dependent on the concurrent presence of glucose (Table 1) but not vice versa (Table 2). There was a sizeable drop in galactose consumption if the media were also supplied with glucose. On the other hand, addition of galactose up to $11.6 \mathrm{mM}$ to various glucose concentrations did not significantly impair glucose consumption.

Fetal human brain and adult rat brain, among many tissues tested, were shown to have the lowest specific activities of the three cytoplasmic enzymes necessary for the conversion of galactose to glucose $(2,5,7,26)$. The rate-limiting enzyme in brain seems to be uridyl-transferase (17). We did not measure enzyme activities in the brain cell cultures but the fact that ${ }^{14} \mathrm{CO}_{2}$ was generated from $\left[\mathrm{U}-{ }^{14} \mathrm{C}\right]$ galactose and label from $\left[1-{ }^{14} \mathrm{C}\right]$ galactose was found in cellular lipids is proof of a functional Leloir pathway. However, flux through this pathway may be limited due to galactokinase which shows substrate and product inhibition and hence could become the rate-limiting step at high galactose levels (7).

Interaction between glucose and galactose metabolism also can be expected at the epimerase step. It has been well documented that NADH is a potent inhibitor of the epimerase reaction (5). At higher levels, more than one-half of the glucose consumed by the brain cells was converted to lactate (Fig. 1 and Table 2). Most likely, this was accompanied by an increase in the intracellular ratios of lactate/pyruvate and NADH/NAD because the lactate dehydrogenase reaction establishes an equilibrium between substrates and the free nucleotides in the cytoplasm (32). It can be speculated that this was a contributory factor for the decreased generation of ${ }^{14} \mathrm{CO}_{2}$ from $\left[\mathrm{U}^{-14} \mathrm{C}\right.$ ]galactose with increasing medium glucose concentrations (Fig. 2). Alternatively, 
Table 5. Incorporation of label from D-[1- ${ }^{14}$ C]galactose into homogenate, nonlipids, and total lipids of neonatal mouse brain cell cultures*

\begin{tabular}{|c|c|c|c|c|c|}
\hline \multirow{2}{*}{$\begin{array}{c}\text { Experimental } \\
\text { group }\end{array}$} & \multirow{2}{*}{$\begin{array}{l}\text { Initial } \\
\text { glucose } \dagger \\
(\mathrm{mM})\end{array}$} & \multirow{2}{*}{$\begin{array}{c}\text { Initial } \\
\text { galactose } \dagger \\
(\mathrm{mM})\end{array}$} & \multicolumn{3}{|c|}{$\mathrm{dpm}\left[{ }^{14} \mathrm{C}\right] / \mathrm{mg}$ cell protein $\times 6 \mathrm{~h}$} \\
\hline & & & Homogenate & Nonlipids & Total lipids \\
\hline $\mathrm{A}$ & 22.95 & 1.1 & $8,131 \pm 544(64)$ & $6,603 \pm 897(23)$ & $669 \pm 55(62)$ \\
\hline B & 4.15 & 1.1 & $14,066 \pm 1,607(48) \ddagger$ & $11,759 \pm 1,208(16) \ddagger$ & $2,107 \pm 353(24) \ddagger$ \\
\hline $\mathrm{C}$ & 0.94 & 1.1 & $10,166 \pm 1,674(19) \ddagger \S$ & $7,903 \pm 953(8) \ddagger \S$ & $2,130 \pm 414(19) \neq$ \\
\hline
\end{tabular}

* Mean $\pm \mathrm{SD}$, no. of experiments in parentheses.

$\dagger$ Media with the specified substrate concentrations were added to the cultures on day 10 and supplemented with $\mathrm{D}$-[1- $\left.{ }^{14} \mathrm{C}\right] \mathrm{galactose}$ on day 13 (1.2-2.4 $\mu \mathrm{Ci}$ per culture).

$¥$ Significantly different from "high glucose" $(22.95 \mathrm{mM})$ group $(p<0.005)$.

$\S$ Significantly different from "intermediate glucose" $(4.15 \mathrm{mM})$ group $(p<0.001)$.

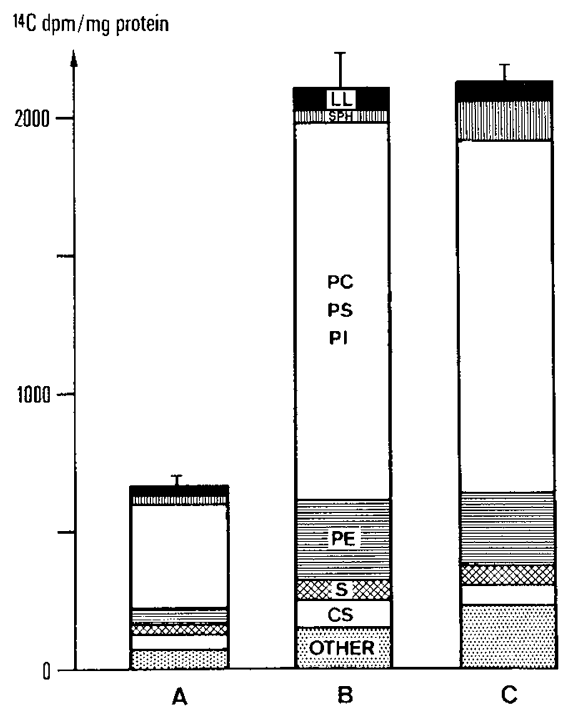

Fig. 3. Incorporation of label from $\mathrm{D}-\left[1-{ }^{14} \mathrm{C}\right]$ galactose into single lipids for the experiments shown in Table 5. LL, lysolecithin; SPH, sphingomyelin; PC, PS, PI, phosphatidyl choline, serine, inositol; PE, phosphatidyl ethanolamine; S, sulfatide; CS, cerebroside; OTHER: cholesterol, free-fatty acids, neutral lipids. Culture media contained $1.1 \mathrm{mM}$ galactose in addition to $22.95 \mathrm{mM}$ glucose $(A), 4.15 \mathrm{mM}$ glucose $(B)$, or 0.094 $\mathrm{mM}$ glucose $(C)$ on day 10 .

in the presence of glucose the label from galactose will become diluted after its entry into the glycolytic pathway and consequently, less label will appear in $\mathrm{CO}_{2}$ and in the cellular homogenate (Table 5). Furthermore, galactose transport could be inhibited by glucose in the 4-h incubations used for the $\mathrm{CO}_{2}$ measurements although no inhibition of galactose consumption was demonstrable in experiments performed over $72 \mathrm{~h}$ with comparable glucose levels up to $4 \mathrm{mM}$ (Table 1), probably because glucose had disappeared from the media in these long-term incubations (level below $0.2 \mathrm{mM}$ ) for the last $36 \mathrm{~h}$.

Lactate was consumed from the media by the brain cells at all galactose levels (Fig. 1): By contrast, lactate was released at considerable rates when the brain cells were supplied with glucose, confirming previous findings (33). The preferential consumption of lactate is further evidence that galactose is an unsuitable energy substrate for brain cells and cannot replace glucose. Lactate has been postulated as an alternate cerebral fuel substrate in the young of several mammalian species (see Ref. 6 for review). In the puppy, the extraction of lactate by the brain appeared to be influenced by the glycemic situation; when the blood glucose concentrations fell there was a net extraction of lactate by brain even though blood lactate concentration had not changed. In a recent report, insulin-induced stupor in suckling mice could be prevented by injection of lactate (30). In vitro, rat brain slices showed a high capacity for lactate oxidation during late gestation and the early postnatal period (1).
Galactose added to different levels of glucose did not influence the consumption of glucose or the formation of lactate compared to experiments without galactose (Table 2). The cell DNA content, as an estimate of cell number, was not significantly different between cultures exposed to glucose and cultures exposed to the same concentrations of glucose with added galactose. The amount of protein as well as the protein/DNA ratio, as an indicator of cell size, did not differ either (data not shown). Therefore, at the concentrations tested, galactose did not exert a toxic effect on DNA content, glucose uptake, or glycolysis if we assume that effects on glycolysis can be assessed by changes in medium lactate. Recently, Segal and Hwang (25) showed that uptake of glucose into isolated rat brain capillaries was not inhibited by preincubation with $50 \mathrm{mM}$ galactose. This is in contrast to many studies in vivo. Haworth et al. (11) demonstrated a $5-15 \%$ decrease in brain DNA content which was associated with reduced body weight in preterm and term fetuses of rats made galactosemic in pregnancy. In the galactose-toxic chick, reduced levels of glycolytic intermediates and brain lactate have been observed repeatedly $(10,14,17)$. Brain glucose $(10,14,16)$ was reduced in this model probably because of the competition between glucose uptake and the excessive plasma galactose levels amounting to $28-56 \mathrm{mM}(14,16)$, and possibly also due to inhibition of several glycolytic enzymes by elevated galactose-1phosphate concentrations (17).

Amazingly, at glucose levels of $7.5 \mathrm{mM}$ or below, which left the brain cells glucose deprived (below $1 \mathrm{mM}$ ) for $24 \mathrm{~h}$ or more, galactose enhanced the incorporation of ${ }^{35} \mathrm{SO}_{4}$ into sulfatide with a maximum effect at around $2 \mathrm{mM}$ (Tables 2 and 3). Sulfatide is a major galactolipid elaborated by oligodendrocytes in the brain cultures $(3,33)$. The last two enzymes in the sulfatide synthesis pathway are UDPgalactose:2-(2-hydroxyacyl)sphingosine galactosyltransferase (EC 2.4.1.45) which converts ceramide to cerebroside, and 3'-phosphoadenylylsulphate:galactosylceramide 3 '-sulphotransferase (EC 2.8.2.11) which by catalyzing the transfer of sulfate to cerebroside forms sulfatide (22). No effect of galactose on sulfatide synthesis was evident at higher glucose concentrations with abundant glucose throughout the experiment and high rates of sulfatide synthesis. A persistently low rate of sulfatide synthesis occurred in the sole presence of galactose with rates nowhere close to those encountered under glucose (Table 4). If some glucose was available, but not enough to keep the cultures fully supplied during the experiment, about twice as much exogenous galactose was incorporated into cerebroside and sulfatide (Fig. $3 B$ and $C$ ) than when glucose was abundant (Fig. $3 A$ ).

After hydrolysis of these galactolipids, over $80 \%$ of the label from $\left[1-{ }^{14} \mathrm{C}\right]$ galactose was identified in the carbohydrate portion of sulfatide and $90 \%$ in the carbohydrate portion of cerebroside. This complements the findings of Poduslo et al. (20) in bulkisolated oligodendrocytes that most radioactivity from exogenous galactose was incorporated into cerebroside. Under all conditions, however, the counts measured in the glycolipid fraction were very modest compared to those in the phospholipids, as confirmed by others (28). Furthermore, only $8-21 \%$ of the 
radioactivity from $\left[1-{ }^{14} \mathrm{C}\right]$ galactose was found in the total lipids fraction of the cellular homogenate (Table 5). In a proper perspective, exogenous galactose stimulated sulfatide synthesis to some extent under conditions of glucose deficiency, most likely by supplying UDPgalactose; but as its overall metabolism by the brain cells was very limited, galactose could not replace glucose as a major fuel substrate.

Acknowledgments. We thank Mrs. Margret Maag-Bieri for her skillful technical help and Miss B. Bilang for her excellent secretarial work.

\section{REFERENCES}

1. Arizmendi C, Medina JM 1983 Lactate as an oxidizable substrate for rat brain in vitro during the perinatal period. Biochem $\mathrm{J} 214: 633$

2. Bertoli D, Segal S 1966 Developmental aspects and some characteristics of mammalian galactose-1-phosphate uridyltransferase. J Biol Chem 241:4023

3. Bologa-Sandru L, Siegrist HP, Z'Graggen A, Hofmann K, Wiesmann U, Dahl D, Herschkowitz N 1981 Expression of antigenic markers during the development of oligodendrocytes in mouse brain culture. Brain Res 210:217

4. Bossi E, Zuppinger K, Siegrist HP, Wiesmann U, Herschkowitz N 1982 Agedependent utilization of $\mathrm{D}-\beta$-OH-butyrate and oleic acid as glucose substitutes by neonatal mouse brain cell cultures. Pediatr Res 16:579

5. Cohn R, Segal S 1969 Some characteristics and developmental aspects of rat uridine diphosphogalactose 4-epimerase. Biochim Biophys Acta 171:333

6. Cremer JE 1982 Substrate utilization and brain development. J Cerebr Blood Flow Metabol 2:394

7. Cuatrecasas P, Segal S 1965 Mammalian galactokinase-developmental and adaptive characteristics in the rat liver. J Biol Chem 240:2382

8. Folch G, Lees M, Stanley GHS 1957 Simple method for the isolation and purification of total lipids from animal tissues. J Biol Chem 226:497

9. Gennari K, Siegrist HP, Burkart T, Bieri M, Wiesmann U, Zuppinger K, Schwarz HP, Herschkowitz N 1981 Utilization of galactose by cultured mouse brain cells. Pediatr Res 15:1191

10. Granett SE, Kozak LP, Mclntyre JP, Wells WW 1972 Studies on cerebral energy metabolism during the course of galactose neurotoxicity in chicks. $J$ Neurochem 19:1659

11. Haworth JC, Ford JD, Younoszai MK 1969 Effect of galactose toxicity on growth of the rat fetus and brain. Pediatr Res 3:441

12. Herschkowitz N, McKhann GM, Shooter EM 1968 Studies of water soluble lipoproteins in rat brain. J Neurochem 15:161

13. Keller K, Lange K, Noske W 1981 D-Glucose transport in cultured cells of neural origin: the membrane as possible control point of glucose utilization. J Neurochem 36:1012

14. Knull HR, Wells WW 1972 Galactose toxicity in the chick: Hyperosmolality or depressed brain energy reserves? Science 176:815

15. Lowry OH, Rosebrough NJ, Farr AL, Randall RJ 1951 Protein measurement with the folin phenol reagent. J Biol Chem 193:265

16. Malone JI, Wells H, Segal S 1972 Decreased uptake of glucose by brain of the galactose toxic chick. Brain Res 43:700

17. Musick WDL, Wells WW 1974 Studies on galactose metabolism in heart and brain: the identification of D-galactose 6-phosphate in brains of galactoseintoxicated chicks and rat hearts perfused with galactose. Arch Biochem Biophys 165:217

18. Oldendorf WH 1971 Brain uptake of radiolabelled amino acids, amines, and hexoses after arterial injection. Am J Physiol 221:1629

19. Pardridge M, Oldendorf WH 1975 Kinetics of blood brain-barrier of hexoses. Biochem Biophys Acta 382:377

20. Poduslo SE, Miller K, McKhann GM 1978 Metabolic properties of maintained oligodendroglia purified from brain. J Biol Chem 253:1592

21. Powell HC, Myers RR 1983 Schwann cell changes and demyelination in chronic galactose neuropathy. Muscle Nerve 6:218

22. Sarliève LL, Rao GS, Campbell GL, Pieringer RA 1980 Investigations on myelination in vitro: biochemical and morphological changes in cultures of dissociated brain cells from embryonic mice. Brain Res 189:79

23. Schwarz HP, Zuppinger K, Schäfer T, Siegrist HP, Wiesmann U, Herschkowitz N 1980 Galactose enhances sulfatide synthesis in glucose-deprived cultured mouse brain cells. Pediatr Res 14:176

24. Segal S 1983 Disorders of galactose metabolism. In: Stanbury JB, Wyngaarden JB, Fredrickson DS, Goldstein JL, Brown MS (eds) The Metabolic Basis of Inherited Disease, 5th ed. McGraw-Hill Co, New York, pp 167-191

25. Segal S, Hwang SM 1983 On the ability of galactose to influence hexose and amino acid uptake by isolated rat brain capillaries. J Neurochem 40:1373

26. Shin-Buehring YS, Beier T, Tan A, Osang M, Schaub J 1977 The activity of galactose-1-phosphate uridyltransferase and galactokinase in human fetal organs. Pediatr Res 11:1003

27. Siegrist HP, Bologa-Sandru L, Burkart T, Wiesmann U, Hofmann K, Herschkowitz N 1981 Synthesis of lipids in mouse brain cell cultures during development. J Neurosci Res 6:293

28. Singh H, Kanfer JN 1981 Incorporation of labelled galactose into glycoconjugates by bulk isolated rat brain astroglial and neuronal cells in vitro. Neuroscience 6:1649

29. Suzuki K 1965 The pattern of mammalian brain gangliosides. II. Evaluation of the extraction procedures, postmortem changes and the effect of formalin preservation. J Neurochem 12:629

30. Thurston JH, Hauhart RE, Schiro JA 1983 Lactate reverses insulin-induced stupor in suckling-weanling mice: biochemical correlates in blood, liver, and brain. J Cerebr Blood Flow Metabol 3:498

31. Wiesmann UN, Hofmann K, Burkart T, Herschkowitz N 1975 Dissociated cultures of newborn mouse brain. 1. Metabolism of sulfated lipids and mucopolysaccharides. Neurobiology 5:305

32. Williamson DH, Lund P, Krebs HA 1967 The redox state of free nicotinamideadenine dinucleotide in the cytoplasm and mitochondria of rat liver. Biochem J 103:514

33. Zuppinger K, Wiesmann U, Siegrist HP, Schäfer T, Sandru L, Schwarz HP Herschkowitz N 1981 Effect of glucose deprivation on sulfatide synthesis and oligodendrocytes in cultured brain cells of newborn mice. Pediatr Res $15: 319$ 